\title{
Počátky jezuitské mise v Číně
}

\author{
Vladimír Liščák \\ Oddělení východní Asie, Orientální ústav Akademie věd České republiky, Pod Vodárenskou věží 4, 18208 Praha 8
}

Do redakce doručeno 23. srpna 2015; k publikaci přijato 5. února 2016

\section{BEGINNINGS OF THE JESUIT MISSION IN CHINA}

ABSTRACT Among the missionaries in China a major role played members of the Society of Jesus, the Jesuits. In course of almost two hundred years they had not only a great numerical superiority among the missionaries, but also developed a method of accommodation for the evangelization of China and played an important role in the imperial court in Beijing. They were popular at Qing emperors for their erudition because they were educated in various sciences such as mathematics, music, geography and cartography. They penetrated on the coast of China since the mid-16th century, but the first missions on the Chinese mainland were founded after the year of 1582 .

KEY WORDS Missionaries in China; Jesuits; beginnings of Jesuit missions

ABSTRAKT Mezi misionáři v Číně hráli nejvýznamnější roli členové Tovaryšstva Ježíšova, jezuité. Po téměř dvě stě let nejenže měli velkou početní převahu mezi misionáři, ale rovněž vyvinuli metodu akomodace pro evangelizaci Číny a hráli významnou roli na císařském dvoře v Pekingu. U čchingských císařů byli oblíbeni pro svou učenost, jelikož byli vzděláni v různých vědách, jako např́iklad v matematice, hudbě, kartografii a geografii. Na pobřeží Číny pronikali již od poloviny 16. století, avšak první misie na čínské pevnině vznikly až po roce 1582.

KLÍČOVÁ SLOVA Misionáři v Číně; jezuité; počátky jezuitských misií

\section{ÚVODEM}

Ve druhé polovině dynastie Ming (v letech 1500 až 1644), tedy v období hlavních evropských zámořských objevů, byl položen důležitý základ pro šíření křestanství v Číně. Zpočátku působili na území Číny jezuitští misionáři, členové Tovaryšstva Ježíšova (latinsky Societas Iesu, SI nebo SJ, S.J.). ${ }^{1}$ Ale

1 Tovaryšstvo Ježišovo vzniklo 15 . srpna 1534, kdy sedm studentů Pařížské univerzity (francouzsky Université de Paris) vedených baskickým knězem sv. Ignácem z Loyoly (1491-1556) složilo vstupní sliby v kapli sv. Denise (francouzsky crypte du martyrium de saint Denis) na Montmartru. Zakládajícími členy nové řeholní společnosti byli vedle Ignáce, který se stal prvním generálem řádu, Navařan sv. František Xaverský (1506-1552), Španělé Alfonso Salmerón (15151585), Diego Laínez Gómez de León (1512-1565) a Alfonso Nicolás Pérez (též Nicolás de Bobadilla, 1509-1590), Savojan sv. Petr Faber (francouzsky Saint Pierre Favre, 1506-1546) a Portugalec Simão Rodrigues de Azevedo (1510-1579). Hlavní činnosti řádu byla misijní, ke konci období přicházeli do Mingské říše misionáři i z jiných řádů, zejména františkáni (členové Řádu menších bratří, latinsky Ordo Fratrum Minorum, OFM, O.F.M.)2 $)^{2}$ dominikáni (členové Řádu bratří kazatelů, latinsky Ordo (Fratrum) Prœ-

vzdělávací a vědecká činnost. 27. záŕí 1540 byl vznik řádu stvrzen bulou Regimini militantis ecclesice Pavla III. (1468-1549, papež v Ř́mě 1534-1549).

2 Řád menších bratří, jehož členové jsou nazýváni františkáni v užším smyslu, bosí františkáni, spirituálové nebo observanti (a v některých regionech Evropy také bernardini nebo reformáti) je jednou $\mathrm{Z}$ větví františkánů, žebravého řeholního řádu založeného sv. Františkem $\mathrm{z}$ Assisi (1182-1226) v roce 1209 a později rozděleného na tř̌i větve (kromě observantů jde ještě o kapucíny a minority). K rozdělení řádu došlo kvůli odkazu sv. Františka - chudobě, nepřijímání privilegií, zdůrazňování poustevnictví či spíše působení ve městech a vzdělávání bratrů. Členové rádu se soustředí především na kazatelskou a misijní činnost. — Blíže viz Buben (2006). 
dicatorum, OP, O.P.) ${ }^{3}$ a augustiniáni (členové Ř́du bratř́i sv. Augustina, též Rád sv. Augustina, Rád poustevníků sv. otce Augustina, latinsky Ordo Fratrum Sancti Augustini, Ordo Sancti Augustini, Ordo Eremitarum S. P. Augustini atd.; O.S.A, O.E.S.A., O.S.Aug.). ${ }^{4}$ Jezuité se v polovině 16 . století usadili v Macau a založili zde univerzitu. Brzy však expandovali do velké části Číny, do různých míst od provincie Kuang-tung na jihu země do Pekingu na dalekém severu. Dominikáni a františkáni pracovali zpočátku převážně v provincii Fu-tien, ale byli prŕtomni také $\mathrm{v}$ Macau.

$\mathrm{V}$ důsledku námořní expanze Portugalska a Španělska ve druhé polovině 15 . století došlo mezi oběma velmocemi ke sporům o nová území. Smlouvou z kastilského Tordesillas (španělsky Tratado de Tordesillas, portugalsky Tratado de Tordesilhas) ze 7. června 1494, podepsanou fakticky na popud Alexandra VI. (1431-1503, papež v Ř́mě 1492-1503) z valencijského rodu Borjů, byl svět nakonec rozdělen na španělskou (západní) a portugalskou (východní) oblast vlivu. ${ }^{5}$

Mezi Svatým stolcem (latinsky Sancta Sedes, italsky Santa Sede) a panovníky Španělska a Portugalska byla uzavřena řada smluv, jež na oba krále delegovaly církevní správu a misionářskou činnost na jejich územích. Španělské právo královského patronátu (španělsky patronato regio) bylo schváleno Juliem II. (1443-1513, papež v Ř́mě 1503-1513) roku 1508, jeho portugalskou obdobu (portugalsky padroado real) potvrdil jeho nástupce Lev X. (1475-1521, papež v Ř́mě 1513-1521) roku $1514 .^{6}$ Toto právo zahrnovalo schvalování a zřizování katedrál, kostelů, klášterů apod. v rámci sfér královských patronátů. Centrem světové misie tak na počátku novověku byly Madrid a Lisabon, nikoli Rím.

Od roku 1576 bylo jedinou diecézí pro Čínu, Japonsko a východoasijské ostrovy Macao, podléhající arcidiecézi v Góji v Portugalské Indii. V roce 1587 se tato diecéze rozděli-

3 Řád bratř́i kazatelů, podle svého zakladatele nazývaný dominikáni, založil v roce 1215 na základě Augustinovy řehole španělský kněz Domingo de Guzmán Garcés (pozdější sv. Dominik, asi 1170-1221). Již roku 1216 se mu dostalo schválení od papeže Honoria III. (asi 1150-1227, papež v Ř́mě 1216-1227). Původním posláním dominikánů bylo kázat, obracet na pravou víru a zpovídat věrící, a působit tak proti šíření herezí, zpočátku především katarského učení $\mathrm{v}$ jižní Francii. Řád neměl vlastnit žádný majetek a jeho členové nebyli vázáni na konkrétní klášter. Měli žít $\mathrm{v}$ chudobě pouze $\mathrm{z}$ almužen. Dominikánské konventy byly zakládány pouze ve městech, nejčastěji u hradeb. Od počátku měl řád velkou podporu papežů, což mu zejména ve 14 . až 16 . století zajistilo rozvoj a popularitu. - Blíže viz Buben (2006).

4 Řád augustiniánů, stručně augustiniáni, je označení pro řeholní společenství, které vzniklo spojením několika poustevnických skupin, řídících se řeholí sv. Augustina (354-430). Takto vznikl řád tzv. obutých augustiniánů, zvaných též augustiniáni-poustevníci. $\mathrm{Z}$ tohoto řádu se později oddělili tzv. bosí augustiniáni. Existuje též samostatný rád augustiniánů-kanovníků, který původně vznikl z kapitul kanovníků při významných kostelích, kteří přijali Augustinovu řeholi. - Blíže viz Buben (2007).

5 Zwettler (1995).

6 Lach (1965), 230-245. la na dvě: Macao a Funay/Funai čili Japonsko. Jezuité, kteří přicházeli do Číny z různých zemí, působili v rámci portugalského „patronátu“. Španělé, kteří měli od konce 16. století základnu na Filipínách, přicházeli do styku s tamními skupinami čínských emigrantů. Španělští dominikáni a františkáni se usazovali v provincii Fu-tien, kam se přepravovali z Filipín přes španělský sever ostrova Taiwan. Tito misionáři, kteří se seznámili s Číňany z jiných oblastí a jiných sociálních vrstev, než s kterými většinou přicházeli do kontaktu jezuité, nakonec vyvinuli odlišný přístup $\mathrm{k}$ misijní práci. Třenice, jež posléze mezi jezuity a ostatními řády působícími v Cíně následovaly, se staly důležitou součástí tzv. sporu o čínské obřady (latinsky quoestio de ritibus Sinensibus), který začal již během mingské éry a probíhal i v průběhu dynastie Čching (1644-1912).

\section{PRVNÍ POKUSY PRONIKNOUT DO ČÍNY}

Čína byla znovu otevřena vnějšímu světu až v polovině 16 . století. Juan de Zumárraga (1468-1548), baskický františkánský biskup a mexický arcibiskup (v letech 1546-1548), provedl roku 1545 předběžné prrípravy pro evangelizaci Číny, a dokonce vyjádřil touhu vzdát se svého biskupství a odejít hlásat evangelium na Filipíny a pokračovat odtud do Číny. Když však františkánská provinční kapitula a Rím odmítly dát souhlas, Zumárraga zůstal v Mexiku a byl v roce 1546 jmenován prvním mexickým arcibiskupem (latinsky archiepiscopus Mexicani, španělsky arzobispo de México)..$^{7} \mathrm{O}$ sedm let později zemřel na Ostrově svatého Jana (Sancian $)^{8}$, asi $14 \mathrm{~km}$ jižně od čínské pevniny, kam plánoval přinést evangelium, spoluzakladatel jezuitského řádu a „apoštol Indií“ (latinsky Indiarum apostolus), navarrský katolický kazatel a misionář sv. František Xaverský (1506-1552).

Již záhy po navázání přímého námořního kontaktu Evropy s Čínou (1513) a založení Tovaryšstva Ježíšova bylo několik Číňanů získáno pro jezuitské úsilí. V roce 1546 se dva čínští chlapci zapsali do jezuitské Koleje svatého Pavla (portugalsky Colégio de São Paulo de Velha Goa) ${ }^{9}$ v Góji, hlavním městě Portugalské Indie. Jeden $\mathrm{z}$ těchto dvou čínských křestanů, známý jako Antonio de Santa Fé, doprovázel jako tlumočník sv. Františka Xaverského na jeho cestě do Číny.

Po misijní práci v Malakce, na Molukách a v jižní Indii v letech 1545 až 1548 odjel František roku 1549 do Japonska, kde působil do roku 1551. Po krátkém pobytu v Indii odplul v roce 1552 zpět do Japonska, a protože se chystal na cestu do Číny,

7 Etulain - Echeverria (1999), 16. - Zumárraga byl prvním Římem jmenovaným biskupem Nového Španělska (dnešního Mexika), kterému císař Karel V. Habsburský (1500-1558, vládl 1516-1556) před odjezdem roku 1527 propůjčil titul „ochránce indiánư“ (španělsky Protector de los indios). - Iraburu (2003), 558.

8 Ostrov svatého Jana (portugalsky Ilha Sanchoão, Ilha São João, čínsky Šang-čchuan-tao 上川島 Shàngchuān Dăo, známý též jako Sancian, $21^{\circ} 39^{\prime} 55^{\prime \prime}$ s. š., $112^{\circ} 47^{\prime} 44^{\prime \prime}$ v. d.), je jeden z ostrovů v Jihočínském moři, jižně od pobřeží provincie Kuang-tung

9 Komplex s bohatou knihovnou byl zničen v roce 1830 . 
vezl s sebou i pověřovací listy pro čínského císaře. Podařilo se mu doplout až na Ostrov svatého Jana, který byl posledním místem, kam tehdy mohli přistát cizinci. Snažil se najít někoho, kdo by byl ochoten riskovat a tajně ho převézt do Číny. Nevyužil ani poslední možnosti opustit ostrov s odplouvajícími portugalskými loděmi. Na ostrově ho v době čekání na odvoz do Číny zachvátila nemoc a František po dvanácti dnech 3. prosince 1552 umírá. ${ }^{10}$

\section{POČÁTKY MISIONÁŘSKÉ ČINNOSTI V ČÍNĚ}

Již od poloviny 16. století do Číny sice přicházeli zejména portugalští jezuité, avšak vzhledem $\mathrm{k}$ malému počtu obyvatel Portugalska ${ }^{11}$ musela portugalská vláda brzy využívat misionáře jiných národností. Př́slušníci jezuitského řádu z jiných zemí však byli nuceni vstoupit do portugalských služeb. Na Východ tak vyplouvali přes Portugalsko a museli mít portugalský pas. ${ }^{12}$ Portugalsko nicméně brzy nebylo schopno řešit nedostatek kněží v misiích, a to jak z vlastních sil, tak pomocí jezuitů $\mathrm{z}$ jiných zemí. Jednou $\mathrm{z}$ možností bylo začít vysílat do Číny kněží ze španělsky mluvících mendikantských ř́dů ${ }^{13}$ (dominikáni, františkáni a augustiniáni), tedy pod patronací španělského patronata, a to i proti vůli Portugalců. ${ }^{14}$ Klement VIII. (1536-1605, papež v Rímě 1595-1605) volil kompromisní řešení a 12. prosince 1600 vydal breve Onerosa pastoralis officii cura ${ }^{15}$, jímž povolil františkánům, kapucínům, dominikánům, augustiniánům a karmelitánům kázat evangelium v Číně a přilehlých ostrovech bez jakéhokoli národnostního omezení, avšak pod portugalským padroadem. Hrozba exkomunikace každému, kdy by toto porušoval, pomáhala udržet v oblasti portugalskou kontrolu. ${ }^{16}$

Padesát misionářů různých katolických řádů se v období let 1552 až 1583 pokoušelo proniknout hlouběji do Číny, většinou přes Kanton: dvacet pět jezuitů ( $\mathrm{z}$ nich sedmnáct kněží), dvacet dva františkáni (jedenáct kněží), dva augustiniáni a jeden

10 Pinch (2011); Fidlerová - Andrle, eds. (2010); Vlčková (2007); Collani (1998).

11 V polovině 16 . století bylo Portugalsko se svými 1,3 milióny obyvatel jedním z nejřidčeji osídlených zemí v Evropě. - Standaert, ed. (2001), 309.

12 Standaert, ed. (2001), 296.

13 Mendikantské řády, též žebravé řády (z latinského mendicans, „žebrajícíc), bylo označení mnišských řádů, které se zřekly vlastnictví nejen na úrovni jednotlivců, ale i společenství jako celku (řádu). Ze středověku dodnes přetrvaly čtyři velké mendikantské řády, uznané Druhým lyonským koncilem (1274): dominikáni (schválení 1216), františkáni (1223), karmelitáni (1245) a augustiniáni-poustevníci (1256).

14 Před rokem 1600 španělští dominikáni a františkáni odcházeli přes Mexiko a snažili se doplout do jižní Číny přes Filipíny, a tak obejít portugalské Macao.

15 Text viz Streit - Dindinger - Rommerskirchen - Kowalsky, V (1964), 987.

16 Jann (1915), 182f; Standaert, ed. (2001), 296. dominikán. ${ }^{17}$ Přestože Čína patřila do oblasti portugalského padroada, pokoušeli se do Číny proniknout i španělští misionáři, kteří jako předmostí využívali tehdy španělské Filipíny. ${ }^{18}$ Nejznámější byly pokusy portugalského dominikána Gaspara da Cruz a navarrského augustiniána Martína de Rada.

Gaspar da Cruz (asi 1520-1570) ${ }^{19}$ působil v Asii od roku 1548, kdy se spolu s deseti dalšími dominikány vylodil v Portugalské Indii. V letech 1554 až 1556 působil v Malakce a Kambodži. $\mathrm{Na}$ konci roku 1556 doplul na Lampacao ${ }^{20}$, malý ostrov v deltě Perlové řeky západně od Macaa, který v polovině 16. století hrál významnou úlohu v čínsko-portugalském obchodu. Během pobytu na Lampacau Cruz obdržel povolení odejít do Kantonu, kde poté asi měsíc kázal. ${ }^{21}$ Krátké období významu Lampacaa skončilo kolem roku 1560, kdy se portugalský obchod přesunul na nově založenou základnu v Macau.

Roku 1557 se Cruz vrátil do Malakky a odtud v roce 1560 zamíril do Hormuzu, kde poskytoval duchovní útěchu vojákům portugalské pevnosti. Po třech letech se pravděpodobně vrátil do Indie. Zpět do Portugalska odešel roku 1565, v roce 1569 pomáhal obětem moru v Lisabonu. Sám se stal obětí moru začátkem února následujícího roku po návratu do kláštera v Setúbalu.

Navarrský augustinián Martín de Rada (1533-1578) byl jedním z prvních augustiniánů, kteři evangelizovali Filipíny, a jedním $\mathrm{z}$ prvních misionářơ, kteří navštívili mingskou Čínu. ${ }^{22} \mathrm{~V}$ roce 1560 odešel jako dobrovolník do Nového Španělska (Mexiko). V Mexiku bylo de Radovi přiděleno studium jazyka otomi ${ }^{23}$, kterým začal úspěšně mluvit již po pouhých pěti měsících. Začal dokonce psát instruktážní kázání a knihy v tomto jazyce.

Nadání a administrativních schopností de Rady si všimli nejen představitelé augustiniánů v Mexiku, ale i jeho nadřízení ve Španělsku. V roce 1565 se zúčastnil expedice na Filipíny, v jejímž čele stál Miguel López de Legazpi y Gurruchátegui (asi 1502-1572), první generální guvernér na Filipínách

\section{Sebes (1988); Tellechea Idígoras (1993).}

18 Křestanskou misi na Filipínách zahájili augustiniáni (1565), následovaní františkány (1577), jezuity (1581) a dominikány (1587). Standaert, ed. (2001), 295.

19 Jeden z prvních křestanských misionářů v Číně a autor pravděpodobně prvního novověkého popisu Číny Tractado em que se cõtam muito por estẽso as cousas da China... - Viz Cruz (1569).

20 Lampacao (čínsky Lang-paj-cao 浪白䆮 Làngbáizào, Lang-paj-ao 浪白澳 Làngbáiảo, či Lang-paj-tiao 浪白滘 Làngbáijiào, kanton-

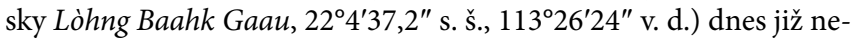
existuje jako samostatný ostrov, nebot' sedimenty ze systému Perlové řeky způsobily, že se stal součástí většího ostrova. Jméno ostrova je známo v mnoha podobách: Lampacau, Lampacam, Lam Puk, Lanpacan, Lampachan, Lampchào, Lamapacào, Lamapzan, Lanpetan, Lampaço, Lampacao, Lampaçao, Lampacão, Lampação, Langpetsao.

21 Borao (2009), 2-3.

22 Ostolaza (2006).

23 Skupina př́buzných jazyků ve středním Mexiku (endonymum:

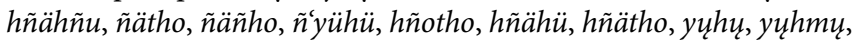
ñuhu, ñotho, ñañu). 
(1565-1572). Tato expedice doplula na filipínský ostrov Cebu 27. dubna 1565. Zde navarrští a baskičtí augustiniáni de Rada, Andrés de Urdaneta y Cerain (1498/1508-1568), Diego de Herrera ( $\dagger 1576)$, Pedro de Gamboa a Andrés de Aguirre (1527-1593) zahájili první novodobou křestanskou misi ve východní Asii.

De Rada se rychle naučil místní jazyk cebuánštinu (sinugboanon, sinebwano). Na Cebu zůstal až do roku 1572 a později získal přízvisko „apoštol křestanské víry na Cebu“. V roce 1572 se stal augustiniánským regionálním superiorem na Filipínách. Ještě na Cebu začal studovat čínský jazyk, takže roku 1574 působil jako tlumočník skupině čínských obchodníků, kteří navštívili Manilu.

Dne 26. června 1575 de Rada a mexický augustinián Jerónimo Marín († 1606) doprovázeli delegaci úředníků do Číny. Do př́stavu Sia-men v provincii Fu-tien dospěli 5. července a navštívili řadu měst. ${ }^{24}$ Skupina se vrátila do Manily dne 28. října 1575. Po svém návratu de Rada sepsal podrobné postřehy o Číňanech a jejich způsobu života. ${ }^{25}$

Mezitím byla dne 7 . března 1575 oficiálně založena augustiniánská Provincie Nejsvětějšího Jména Ježíš na Filipínách (španělsky Provincia del Santísimo Nombre de Jesús de Filipinas). ${ }^{26} \mathrm{Na}$ její prŕípravě se po roce 1565 účastnil i de Rada. $\mathrm{V}$ roce 1578 byl vyslán guvernérem Manily na Borneo, kde měl urovnat spor v sultánově rodině. Expedice však nebyla úspěšná a de Rada na zpáteční cestě onemocněl a krátce před přistáním v Manile zemřel.

\section{PRVNÍ JEZUITÉ V ČÍNĚ}

Mezi prvními jezuity na území Číny byl Melchior Núnes Barreto (asi 1520-1571). Do jezuitského řádu vstoupil v Coimbře v březnu 1543. V roce 1551 odešel do tehdy portugalské Indie, kde ho sv. František Xaverský jmenoval rektorem koleje v Baçaimu (dnešní Vasai, severně od Bombaje). Po smrti Františka Xaverského se roku 1553 stal provinciálem Indie a roku 1554 odešel do Číny.

Jako první evropský misionář navštívil jihočínský Kanton, a to dvakrát (v červenci a srpnu 1555), aby osvobodil Portugalce Matea de Brito, který tam trávil šest let ve vězení; v obou případech musel Núnes po měsíci odejít. Potřetí přišel do Kantonu během postu před Velikonocemi roku 1556 a poté pokračoval do Japonska. V červnu 1556 se připojil k portugalské misii v tehdejší japonské provincii Bungo (japonsky 豊後国 Bungo no kuni) na východě ostrova Kjúšú. Následujícího roku (1557) se vrátil do Indie, kde se stal rektorem jezuitské koleje v Kóčínu. ${ }^{27}$

Jedním z prvních jezuitských misionářů na Dálném východě

24 Boxer - Pereira - Cruz - Rada (1953).

25 Relaçion Verdadera delascosas del Reyno de TAIBIN ... - Viz Rada (1575).

26 Pérez (1901).

27 Borao (2009). a spolupracovníkem sv. Františka Xaverského, průkopníka této mise, byl Baltasar Gago (asi 1515/1520-1583). Do jezuitského řádu vstoupil v roce $1546 \mathrm{v}$ Lisabonu. 17. března téhož roku vyplul na lodi São Pedro na východ. Svou misionářskou kariéru zahájil v Góji a roku 1550 založil jezuitskou rezidenci v jihoindickém Kóčínu.

V roce 1552 doprovázel Františka Xaverského a některé další jezuity na východ, v Malakce se však rozdělili: František odešel do Č́ny a Baltasar směřoval do Japonska, kam dorazil roku 1555. Působil v provincii Bungo, v Hiradu (平戸市 Hirado-shi) $\mathrm{v}$ prefektuře Nagasaki založil katolickou komunu, která čítala 500 členů. Mezi konvertity byli i př́slušníci vysoké šlechty (japonsky daimjó 大名 daimyō; doslova „velké jméno“).

Z Japonska odplul roku 1560 na ostrov Chaj-nan v Jihočínském moři, kde pobyl několik měsíců (listopad 1560 až květen 1561). Krátce pobýval také v Macau (do 1. ledna 1562), kde se jezuité snažili vybudovat základnu pro mise v Japonsku a Číně. V té době bylo v Macau na 500 až 600 Portugalců. Z Macaa odešel přes Malakku do Góy, kde působil až do své smrti. ${ }^{28}$

K prvním španělským jezuitů a spolupracovníkům sv. Františka Xaverského ve východní Asii patřil Francisco Pérez (15141583). Do jezuitského řádu vstoupil 25. ledna 1544 v Coimbře v Portugalsku. Dne 8. dubna 1546 vyplul na lodi Flor de la Mar a jeho první zastávkou byla - jak bylo v té době obvyklé - Góa v Portugalské Indii. Poté pokračoval do Malakky, kde roku 1548 založil jezuitskou rezidenci. V roce 1552 byl jmenován superiorem indické mise.

V dubnu 1562 odplul do Kantonu a 28. srpna (či července?) následujícího roku (1563) vstoupil do Macaa (in Sinis) s poselstvem portugalskéhokrále, vedeným Diogem(Diegem) Pereirou (1563-1565 capitão-mor de Macau $^{29}$ ). V Macau Pérez spolu s otcem Manuelem Teixeirou a Andrém Pintem založil roku 1565 jezuitskou rezidenci se školou ${ }^{30}$ a do prosince 1565 byl jejím prvním ředitelem. Dne 21. listopadu 1565 navštívil opět Kanton, aby předložil čínským hodnostářrum dvě memoranda psaná portugalsky a čínsky, v nichž vysvětloval, kdo je a žádal o povolení usadit se v Č́ně. Hodnostáři jeho žádost odmítli s tím, že pro cizince platí absolutní zákaz trvale pobývat v Číně. V roce 1568 Pérez odešel zpět do Góy.

André Pinto (asi 1538-1588) vstoupil do jezuitského řádu v Góji v květnu 1557. Na východní misi odjel přes Malakku (1562) a 28. srpna (či července?) 1563 připlul do Macaa spolu s Franciskem Pérezem a Manuelem Teixeirou v poselstvu Dioga Pereiry. Na konci listopadu 1564 vykonal krátkou návštěvu Kantonu. V roce 1569 se vrátil do Góy a roku 1577

28 Cieslik (1954), Dehergne (1940).

29 Capitão-mor de Macau byl titul vojenského velitele Macaa před zavedením funkce guvernéra.

30 Škola sloužila $\mathrm{k}$ př́pravě jezuitských misionářů, kteří cestovali do východní Asie. Roku 1594 ji Alessandro Valignano (1539-1606) povýšil na univerzitu s názvem Kolej svatého Pavla (portugalsky Colégio de São Paulo, též Kolej Matky Boží, portugalsky Colégio da Madre de Deus). Byla to první univerzita západního typu ve východní Asii, s rozsáhlým studijním programem odpovídajícím osnovám univerzity. 
odešel na misi do Japonska, později ho opět nacházíme v Macau. V roce 1581 doprovázel Michela Ruggieriho (1543-1607) během jeho krátké návštěvy Kantonu. Roku 1584 byl v Macau jmenován jezuitským prokurátorem pro mise v Indii a Japonsku.

Další z této skupiny prvních jezuitů Manuel Teixeira (15361590) opustil Portugalsko 10. března 1551 a v záŕí téhož roku připlul do Góy. Na počátku roku 1552 se zde setkal se sv. Františkem Xaverským, který se chystal na svou cestu na východ. V roce 1562 odjel Teixeira do východní Asie přes Malakku a 28. srpna (či července?) 1563 připlul do Macaa spolu s Franciskem Pérezem a Andrém Pintem ve vyslanecké misi Dioga Pereiry. Na konci ledna 1564 odešel spolu s Baltasarem da Costa na ostrov Ilha do Pinhal, známější dnes jako Lantau (čínsky Ta-jü-šan 大嶼山 Dàyǔshān), nedaleko od Macaa (dnes součást Hongkongu). Otec Teixeira se také dvakrát účastnil obchodní mise do Kantonu (18. listopadu až 1. prosince 1564 a 21. listopadu až začátek prosince 1565).

V roce 1565 spolu s Franciskem Pérezem založil v Macau jezuitskou rezidenci, pozdější Kolej svatého Pavla při katedrále Matky Boží. Ve stejném roce byl Teixeira spoluzakladatelem jezuitské katedrály svatého Pavla (portugalsky Igreja de São Paulo, později přejmenované na katedrálu Matky Boží, Igreja da Madre de Deus). V roce 1835 katedrála vyhořela a dochovalo se pouze její průčelí, které patří k nejvýznamnějším památkám Macaa. ${ }^{31}$ Roku 1568 se otec Teixeira vrátil do Góy. V letech 1569-1572 byl rektorem jezuitů v Kóčínu a 1573-1574 viceprovinciálem pro Indii. ${ }^{32}$

Prvním jezuitským biskupem v Číně, respektive v Macau, byl Melchior Miguel Carneiro Leitão (1516-1583). Do jezuitského řádu vstoupil 14. března 1543 v Coimbře a 25 . dubna byl vysvěcen na kněze. V roce 1551 byl jmenován prvním rektorem jezuitské Koleje Ducha svatého v Évoře (portugalsky Colégio do Espírito Santo), pozdější slavné univerzity. 23. ledna 1555 byl jmenován titulárním biskupem ${ }^{33}$ níkajským (latinsky episcopus titularis Nicœenus) ${ }^{34}$ ve funkci pomocného biskupa nově jmenovaného etiopského patriarchy. Protože však brzy nato odjel do Góy, nemohl být vysvěcen v Portugalsku (vysvěcen byl nakonec až 15. prosince 1560).

$\mathrm{V}$ breve Ex Litteris carissimis z 2. února 1566 byl Piem V. jmenován apoštolským administrátorem ${ }^{35}$ pro portugalské

31 Ruínas de São Paulo (čínsky Ta-san-pa pchaj-fang 大三巴牌 坊 Dàsānbā Páifāng) jsou součástí památek UNESCO v historickém centru Macaa od roku 2005.

32 Braga (1949); Wicki (1952).

33 Titulární biskup (latinsky episcopus titularis), „biskup v krajích nevěŕcích" (latinsky episcopus in partibus infidelium) bylo označení biskupa, který nespravoval skutečnou diecézi, ale diecézi zpravidla již zaniklou.

34 Titulární biskupství pojmenované podle starobylé Níkaje (řecky Níkaı a latinsky Nicaea). Bylo to historické město v severozápadní Anatolii, na území dávné Bithýnie, v dnešním Turecku, známé především jako místo konání dvou ekumenických koncilů starověké křestanské církve. Současné moderní město se jmenuje İznik.

35 Apoštolský administrátor (latinsky administrator apostolicus) mise v Japonsku a Číně. Až do roku 1567 však pokračoval v misionářské činnosti na Malabárském pobřežǐi ${ }^{36} \mathrm{v}$ Portugalské Indii. Tehdy byl pozván, aby přišel do Macaa, kde jezuité zřídili misi.

Do Macaa připlul v červnu 1567, a stal se tak prvním vysvěceným biskupem v oblasti Číny a Japonska. V roce 1569 založil Nemocnici pro chudé (portugalsky Hospital dos Pobres; pozdější Nemocnice svatého Rafaela, Hospital de São Rafael) a Svatý dům milosrdenství (portugalsky Santa Casa da Misericórdia), první evropskou charitativní organizaci v Macau. ${ }^{37}$ Kromě toho založil nedaleko katedrály sv. Pavla i leprosárium pro péči o malomocné. ${ }^{38}$

Jeho dílo bylo završeno, když papež Řehoř XIII. (1502-1585, papež v Rímě 1572-1585) zřídil bulou Super Specula Militantis Ecclesioe $^{39}$ z 23. ledna 1576 Macaoskou diecézi. Prvním papežským kandidátem na biskupa Macaa však nebyl Carneiro, ale Diogo Nunes de Figueira (latinsky Didacus Nunnez Figueira). Ten nicméně jmenování odmítl a nikdy do Macaa nepřijel. Druhým kandidátem byl Leonardo Fernandes de Sá († 1597), sekulární kněz z Kristova řádu ${ }^{40}$, který byl potvrzen biskupem Macaa 22. ledna 1578. Do Macaa však připlul až v roce 1581. Do té doby Carneiro tedy sloužil jako administrátor nové diecéze (1576 až 1581). Přestože nebyl oficiálně jmenován biskupem Macaa, je považován za prvního biskupa v Č́ně a Japonsku. V roce 1577 byl Carneiro jmenován nominálním patriarchou Etiopie (latinsky Patriarcha Æthiopiensis, 1577-1581), ačkoli sám tam - vzhledem k působení ve východní Asii - nemohl odcestovat. $^{41}$

je prelát (může to být kněz nebo biskup) ustanovený papežem, aby jako ordinář vykonával správu nad apoštolskou administraturou, nad diecézí, která nemá biskupa, nebo (výjimečně) nad diecézí, jejíž biskup nemůže správu vykonávat.

36 Malabárské pobřeží v jihozápadní Indii má dlouhou křestanskou tradici. Dosud zde žijí křestané, kteří odvozují svůj původ od prvních indických křestanů, údajně pokřtěných sv. Tomášem. Křestané sv. Tomáše je název pro různé denominace křestanské církve v Indii, zejména na Malabárském pobřeží, uctívající sv. Tomáše. Mezi prvními konvertity byli místní židovští osadníci i původní obyvatelé. - O malabárských křestanech existuje bohatá literatura, viz např. Menachery $(1973,1987,1998)$.

37 Teixeira (1970).

38 Standaert, ed. (2001), 793.

39 Jordão, ed. (1868), 243-245. Datováno v Rímě: „Datum Romøe apud Sanctum Petrum, anno Incarnationis Dominica MDLXXV, kal. $X$ Februarii, Pontificatus nostri anno quarto“. (23. ledna $1575=23$. ledna 1576 podle našeho počítání.)

40 Kristův řád (portugalsky Ordem de Cristo, Ordem de Nosso Senhor Jesus Cristo, plným názvem Řád rytírů našeho Pána Ježíše Krista, portugalsky Ordem dos Cavaleiros de Nosso Senhor Jesus Cristo) byl původem portugalský rytířský řád založený králem Dinisem I. (1261-1325, vládl 1279-1325) v souvislosti se zánikem templárư asi v roce 1317 či 1318 a potvrzený bulou Ad ea ex quibus Jana XXII. (1249-1334, papež v Avignonu 1316-1334) ze 14. března 1319. Kristův řád převzal portugalské majetky templářu a snad i část členů tohoto zrušeného řádu.

41 Teixeira (1976), 43-44. 
V srpnu 1568 připlul do Macaa Francisco Cabral ( 1528/1529-1609). Do jezuitského řádu vstoupil v Góji $\mathrm{v}$ roce 1554 a působil tam až do roku 1568, kdy odešel na svou východní misi. Nejdř́ve působil dva roky v Macau (srpen 1568 až červen 1570). Dne 18. června 1570 odešel do Japonska, kde působil jako superior mise až do 8. října 1581. Když se Japonsko stalo jezuitskou viceprovincií, stal se jejím prvním viceprovinciálem (1582-1583?).

Poté odešel do Macaa, kde byl v letech 1583 až 1584 rektorem Macaoské koleje (portugalsky reitor do Colégio de Macau) a superiorem čínské mise (latinsky superior Missionis Sinicae Societatis Iesu). Roku 1584 založili jezuité první misii v pevninské Číně v Shiuhingu (též Sauguin, tj. Čao-čching 肇慶 Zhàoqing, provincie Kuang-tung) a Cabral byl jedním z prvních misionářů, kteří zde působili (od 21. listopadu 1584). V prosinci 1586 Macao opustil a odešel znovu do Góy, kde v letech 1592 až 1597 působil jako provinciál Indie (či Indií, jak se tehdy používalo). ${ }^{42}$

Jedním z prvních španělských jezuitů v Číně byl Pedro Riera (asi 1526-1573). Do jezuitského řádu vstoupil 11. března 1548 v Ř́mě. Dne 25. března 1565 odjel na lodi Esperança do Góy. V srpnu 1567 přijel do Macaa spolu s Juanem Baptistou de Ribera ( $\left.{ }^{*} 1525-1594\right)$. Diego Laínez Gómez de León (1512-1565), generál jezuitského řádu (1558-1565), jim před jejich odjezdem z Evropy výslovně doporučil, aby vyvinuli veškeré úsilí pro vstup na území Číny. V říjnu 1568 vstoupili na předměstí Kantonu, kde nejprve žádali magistrátní úředníky o povolení ke vstupu do města, což jim bylo odmítnuto. Otec Ribera se proto rozhodl tam vstoupit tajně, bez vědomí a schválení svých nadřízených. Avšak jeho převozník ho místo toho přivezl zpátky do Macaa.

\section{POČÁTKY JEZUITSKÉ MISE A ZROD AKOMODAČNÍ METODY}

Novověké mise na čínské pevnině začaly až roku 1582, kdy italští jezuité Matteo Ricci (1552-1610) a Michele Ruggieri (1543-1607), působící v rámci portugalského padroada, získali povolení zrrídit stálou misii v Čao-čchingu (Sauguin) v jižní Číně. Jezuité v době Mattea Ricciho byli první, kdo položili solidní základ pro misie v Čínské říši. Postupovali přes provincii Kuang-tung do středočínských provincií a měst, Nankingu, Šanghaje a Chang-čou a snažili se dojít do Pekingu. Svým breve Ex pastorali officio ${ }^{43} \mathrm{z} 28$. ledna 1585 dal Řehoř XIII. jezuitům exkluzivní právo šírit evangelium v Japonsku a Číně pod patronátem Portugalské koruny. To jim umožnilo nezávisle rozvíjet svou vlastní misijní metodu.

Pro „jezuitskou misionářskou strategii“ v Číně byla od počátku určující akomodační metoda. Tato strategie byla koncipována Alessandrem Valignanem (1539-1606), někdejším novicmistrem Mattea Ricciho a v letech 1574 až 1606 jezuit-

42 Da Vita e morte do Padre F.C., ms de JA 49-VI-8 ff. 103-111.

43 Text viz Streit - Dindinger - Rommerskirchen - Kowalsky, IV (1964), 1647. ským apoštolským vizitátorem (latinsky visitor apostolicus) ${ }^{44}$ pro východní Asii. ${ }^{45}$ Jeho strategie byla později kreativně začleněna do praxe Mattea Ricciho. Následující generace proto až do 18. století spojovaly tuto strategii především s Riccim a nazvali ji „Ricciho metoda“.

Valignano, který byl ze své dřívější praxe zklamán omezenou mírou inkulturace japonské kultury ze strany jezuitů, trval v Číně především na znalosti čínského jazyka. Proto v roce 1579 povolal několik jezuitů do Macaa a nařídil jim zaměřit pozornost výhradně na studium jazyka. $\mathrm{O}$ dva roky později vstoupil z jihu do Číny Michele Ruggieri a rok nato ho následoval Matteo Ricci. Inspirováni pravděpodobně japonskou situací, oblékali se první jezuité v Číně jako buddhističtí mniši. V roce 1595, po téměř patnácti letech zkušeností, změnili svou politiku a přizpůsobili se životnímu stylu a etiketě konfuciánské elity literátů a úředníků. $\mathrm{O}$ tuto změnu se zasloužil především Matteo Ricci.

Nová politika zůstala nezměněna po celé 17 . století a pro většinu jezuitských misionářů se př́stup Mattea Ricciho stal vzorem akomodační politiky. V roce 1597 ho Valignano jmenoval hlavním jezuitským misionářem pro území Č́ny. Ricciho způsob akomodace na čínské prostředí a náboženství spočíval - stejně jako $u$ jeho druhů a pokračovatelů (mezi nimiž bylo $\mathrm{v}$ dalších letech i osm prŕslušníků české řádové provincie) - především v dokonalém zvládnutí čínštiny, ve znalostech historie čínského národa, jeho světských a duchovních tradic a v navazování dialogu s místními učenci-literáty. Již to byl svým způsobem výrazný ústupek křestanské nadřazenosti a uznání čínské vzdělanosti.

Matteo Ricci i ostatní jezuitští misionáři ke značné nelibosti příslušníků jiných řeholí působících tehdy v Číně tvrdili, že přirozená a dávná čínská zbožnost, představy Číňanů o Bohu atd. vlastně v křestanství docházejí pouze svého dovršení, že křestanské učení, at zjevené, či posvěcené tradicí, vede k lepšímu chápání jejich vlastního duchovního dědictví. Všechny přirozené hodnoty čínské kultury měly být tudíž zachovány i v přijatém křestanství. Mezi těmito hodnotami měl své přirozené místo i dávný kult předků a úcta k filosofovi Konfuciovi. Tento jezuitský prrístup kladně oceňovali také čínští císařové jak z dynastie Ming, tak zejména $\mathrm{z}$ následující mandžuské dynastie Čching - a to jednak svými tolerančními edikty (např́klad z let 1657 a 1692), jednak celkově příznivým vztahem k cizímu učení a jeho hlasatelům.

Ricci byl toho názoru, že vynikající etická a sociální doktrína konfuciánství by měla být doplněna o metafyzické myšlenky křestanství. Hájil návrat $\mathrm{k}$ původnímu konfuciánství, které považoval za filosofii založenou na přirozeném právu. Podle jeho názoru obsahuje ideu Boha. Nakonec přijal tolerantní postoj $\mathrm{k}$ určitým konfuciánským obřadům, jako uctívání předků a úctu ke Konfuciovi, jež brzy byly označeny za „občanské obřady“. Tato politika byla v kontrastu s tou, již přijaly

44 Apoštolský vizitátor je $\mathrm{v}$ římskokatolické církvi papežský zástupce $\mathrm{s}$ přechodným posláním $\mathrm{k}$ provedení kanonické vizitace relativně krátkého trvání.

45 O Valignanovi viz podrobněji např. Collani (1997). 
ostatní tehdejší řády, zejména františkáni a dominikáni. Tyto řády se ukázaly být méně akomodativními, méně orientovanými na vzdělance, méně se zabývajícími vědami a méně tolerantními vůči místním rituálním tradicím. ${ }^{46}$

Jedním z prvních jezuitských misionářů v Číně byl Michele Ruggieri (1543-1607). ${ }^{47}$ Před tím, než vstoupil do jezuitského řádu (v Rímě 28. řína 1572), získal v Neapoli doktorát obojího práva (latinsky in utroque iure), tj. práva civilního a kanonického. Po dokončení obvyklé jezuitské duchovní a intelektuální formace, odjel do Lisabonu, výchozí brány všech misionářů, kteří odcházeli v rámci portugalského patronátu do východní Asie.

Zatímco čekal na lod' do Góy, byl v březnu 1578 vysvěcen na kněze. Brzy po vysvěcení opustil břehy Evropy a vydal se spolu s dalšími dvanácti misionáři do Indie, kam připluli v zárí 1578. Mezi nimi byli např́klad bl. Rodolfo Acquaviva (1550-1583) a Matteo Ricci.

Ruggieri začal okamžitě studovat jeden $\mathrm{z}$ jazyků používaných na Malabárském pobřeží a za šest měsíců dosáhl takové dokonalosti, že mohl provádět zpověd. Pravděpodobně toto jeho nadání pro jazyk ho předurčilo pro začátek čínské mise. S několika společníky Ruggieri odplul do Macaa na pobřeží Čínské říše. Přistál v tomto portugalském obchodním centru 20. července 1579 a ihned se začal učit čínsky. S vědomím toho, že ho mnozí budou následovat, založil Školu svatého Martina (italsky la casa di San Martino, čínsky Šeng Ma-ting ting-jüan 聖瑪定經院 Shèng Mǎding jīngyuàn, nebo Šeng Ma-er-ting tïng-jüan 聖瑪爾定經院 Shèng Măěrding jīngyuàn), první školu pro výuku čínštiny pro cizince. ${ }^{48}$

O něco později, 7. srpna 1582, připlul do Macaa i Ricci. V jeho doprovodu byl misionář a malír Giovanni Niccolò (15601626), který v Macau založil první evropskou malířskou školu v Asii a o něco později (1603?) podobnou školu založil i během své mise $\mathrm{v}$ japonském Nagasaki. Podle jiných údajů odešel z Macaa do Japonska již v roce 1583 a malířskou akademii (italsky Seminario dei Pittori) v Nagasaki založil roku 1590. ${ }^{49}$ Ruggieriho i Ricciho úmyslem však po celou dobu bylo usadit se někde ve „skutečné“ Číně - nikoli pouze v Macau. Ruggieri proto několikrát navštívil Kanton a Čao-čching a navázal užitečné kontakty s místními úřady. Stal se tak jedním z prvních novověkých křestanských misionářů, kteři navštívili pevninskou Čínu. ${ }^{50}$ Po řadě neúspěšných pokusů bylo nakonec povolení ke zrrízení stálé mise v Číně uděleno v prosinci 1582 a v roce 1583 se Ricci a Ruggieri konečně usadili v Čao-čchingu na pozvání tehdejšího prefekta Wang Pchana (王泮 Wáng $P a ̀ n)$, který slyšel o Ricciho schopnostech matematika a kar-

\section{Kolmaš (1999).}

47 O Ruggierim podrobněji viz Collani (1994).

48 Piccinini (2011).

49 Často se reprodukuje jeho údajný portrét daimjóa Ody Nobunagy (織田信長, 1534-1582), který je však datovaný do let 15831590 , tedy již po Odově smrti.

50 Srv. první návštěvu španělských misionářủ v Čao-čchingu $\mathrm{v}$ roce 1579. tografa. Ricci zůstal v Čao-čchingu až do roku 1589, kdy ho nový místokrál z města vykázal.

Právě zde v roce 1584 Ricci sestavil první mapu světa v čínštině v evropském stylu a zahrnující i americký kontinent. Žádný původní výtisk mapy se však nedochoval, dochovalo se pouze šest verzí na rýžovém papíru. Mapa nesčetných zemí světa (čínsky Kchun-jü wan-kuo čchüan-tchu 《坤輿萬國全圖》 Kūnyú wànguó quántú, italsky Carta Geografica Completa di tutti i Regni del Mondo) byla vytištěna v Pekingu roku $1602 .{ }^{51}$ Během pobytu v Čao-čchingu vydal Ruggieri v roce 1584 $\mathrm{v}$ čínštině katechismus Pravdivý záznam o posvátném učení katolické církve (čínsky Tchien-ču šeng-tiao 苂-lu 《天主聖教 實錄》Tiānzhǔ shèngjiào shílù), první čínskou křestanskou knihu napsanou Evropanem. ${ }^{52} \mathrm{~V}$ letech 1583 až 1588 vytvořil Ruggieri spolu s Riccim a čínským laikem Sebastiánem Fernándezem (čínským jménem Čung Pa-siang 鐘巴相 Zhōng Bāxiāng, též Čung Ming-žen 鍾明仁 Zhōng Míngrén, psáno též 鍾鳴仁, 鍾銘仁, 1562-1621) Portugalsko-čínský slovník (čínsky Pchu-Chan cch'-tien 《葡漢辭典》Pú-Hàn cídiăn), první slovník mezi čínštinou a evropským jazykem, pro nějž také navrhli systém přepisu čínských jmen do latinky. Bohužel se rukopis v jezuitském archivu v Rímě ztratil a znovu byl objeven teprve v roce 1934 díky Pasqualu Mariovi d'Elia (1890-1963), jezuitskému misionáři v Číně, sinologovi a misiologovi. Tento slovník byl nakonec publikován až $\mathrm{v}$ roce $2001 .^{53}$

V listopadu 1588 Ruggieri opustil Čínu a odjel do Ríma, aby přiměl papeže odeslat poselstvo $\mathrm{k}$ čínskému císaři. Účelem bylo umožnit jezuitům dojít do Pekingu a dosáhnout přijetí císařem. Přimět papeže $\mathrm{k}$ navázání diplomatických styků s mingskou Čínou se mu však nepodařilo, nakonec se uchýlil do Salerna, kde překládal do latiny konfuciánské spisy $^{54}$, psal poesii v čínštině a vydával mapy Číny.

Matteo Ricci po odchodu z Čao-čchingu v roce 1589 získal povolení usadit se v Šao-kuanu (韶關 Sháoguān, $24^{\circ} 49^{\prime}$ s. š., $113^{\circ} 35^{\prime}$ v. d.) na severu provincie Kuang-tung. Ve městě zůstal několik let, a protože Šao-kuan ležel na významné severo-jižní trase, podařilo se mu navázat kontakty s projíždějícími hodnostáři, kteří mu umožnili přesunout se na sever, do Nan-čchangu (南昌 Nánchāng, $28^{\circ} 41^{\prime}$ s. š., $115^{\circ} 53^{\prime}$ v. d.) v provincii Ťiang-si, do Nankingu, a nakonec do Pekingu, kam se natrvalo přestěhoval roku 1601.

V Pekingu se Ricci vedle vlastní misijní práce věnoval především rozsáhlé vědecké činnosti v oblasti matematiky, mechaniky, chemie, lékařství, astronomie, geografie a kartogra-

51 D’Elia (1938), Urschel (2010).

52 Ruggieri (1584). Faksimile tisku Borg.Cin 324 z Vatikánské knihovny viz <http://archives.catholic.org.hk/Rare\%20Books/CTJ1/ index.htm $>$.

53 Ruggieri - Ricci; Witek, ed. (2001).

$54 \mathrm{~V}$ roce 1593 vydal překlad části Velkého učení (čínsky Ta-süe 《大學》Dàxué). — V: Antonii Possevini Societatis Iesv Bibliotheca selecta qua agitur de ratione stvdiorum in historia, in disciplinis, in salute omnium procuranda. T. I. Romæ, Ex Typographia Apostolica Vaticana, M. D. XCIII. (1593), lib. IX: 583. 
fie a v těchto oborech také hojně publikoval, většinou čínsky. Ricci byl vůbec prvním Evropanem, kterému se podařilo dostat se do Zakázaného města. V Pekingu zůstal až do své smrti roku $1610 .{ }^{55}$ Během tohoto pekingského období se mu podařilo přivést ke konverzi řadu tamějších obyvatel včetně některých vysoce postavených úředníků. Ricci měl pozoruhodný úspěch $\mathrm{v}$ evangelizačním díle pro velkou toleranci, již prokazoval kultu, kterým Č́ńnané uctívali Nebe, Konfucia a předky.

\section{ZÁVĚREM}

Jednou z charakteristik raného období jezuitské přítomnosti v Číně byla neprrímá propagace za využití evropské vědy a technologie s cílem přilákat pozornost vzdělaných Číňanů a přesvědčit je o vysoké úrovni evropské civilizace. Jezuité nabízeli císaři a dvorským hodnostářmu evropské hodiny, představovali obrazy, které Číňany překvapovaly použitou perspektivou, přeložili matematické spisy Eukleida z Alexandrie $^{56} \mathrm{~s}$ komentáři slavného německého jezuitského matematika a astronoma Kryštofa Clavia (1538-1612) $)^{57}$, pracovali $\mathrm{v}$ Astronomickém úřadu v Pekingu, psali knihy o kalendáři (gregoriánská reforma 1582) (58 $^{5}$ zemědělství, technice, tiskli mapy, které integrovaly výsledky nejnovějších objevů světa.

55 Jako první byl pohřben na jezuitském hřbitově Ča-lan (čínsky Tcheng-kung ča-lan 滕公柵欄 Ténggōng zhàlán, též Ča-lan mu-ti 柵欄墓地 Zhàlán mùdì) v Pekingu. Do roku 1900 zde pohřbeno 88 západních misionářů, $\mathrm{z}$ nich většina byli jezuité. Dodnes se zachovalo 63 náhrobků.

56 Eukleidovy Základy (starořecky $\Sigma \tau$ тoıعĩa Stoicheía), jejichž au-

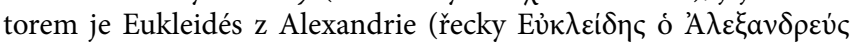
Eúkleídēs ho Alexandreús, asi 325 př. n. 1. - asi 260 př. n. 1), byly až do druhé poloviny 19. století po bibli nejvíce rozšíreným dílem světového písemnictví. Jeho dílo nám podává přehled o matematických znalostech Řeků ke konci 4. století př. n. l. Základy jsou učebnicí matematiky, která se skládá z 13 knih. Dnes víme, že pocházejí od několika autorů a jsou založeny zčásti na starších zdrojích.

57 Clavius (1574, 1589, 1603a).

58 Clavius (1603b).

\section{BIBLIOGRAFIE}

\section{Prameny}

Boxer, Charles Ralph - Pereira, Galeote - Cruz, Gaspar da - Rada, Martín de (1953): South China in the sixteenth century: being the narratives of Galeote Pereira, Fr. Gaspar da Cruz, O.P. (and) Fr. Martín de Rada, O.E.S.A. (1550-1575), Issue 106 of Works issued by the Hakluyt Society, Printed for the Hakluyt Society (Includes English translations of two of de Rada's reports, with C.R. Boxer's comments). London, Printed for the Hakluyt Society.

Clavius, Christophorus, S.I. (1574): Euclidis Elementorum libri XV, accessit XVI. de solidorum, regularium comparatione omnes perspicuis demonstrationibus accuratisque scholiis illustrati auctore Christophoro Clavio. Romæ, apud Vincentium Accoltum.
Clavius, Christophorus, S.I. (1589): Euclidis Elementorum Libri XV, Accessit $X V I$. de solidorum regularium cuiuslibet intra quodlibet comparatione, omnes perspicuis demonstrationibus accuratisque scholiis illustrati. Nunc iterum editi ac multarum rerum accessione locupletati. Auctore Christophoro Clavio Bambergensi e Soc. lesu. Romæ, Bartholomæum Grabium.

Clavius, Christophorus, S.I. (1603a): Euclidis posteriores libri IX. Accessit liber $X V I$. de Solidorum Regularium cuiuslibet intra quodlibet comparatione. Omnes perspicuis demonstrationibus accuratisque scholiis illustrati nunc quarto editi ac multarum rerum accessione post primam editionem locupletati. Auctore Cph. Clavio Bambergensi e societate Iesu. Romæ, apud Aloysium Zannettum, Permissu Superiorum. MDCIII [1603].

Clavius, Christophorus, S.I. (1603b): Romani calendarii a Gregorio XIII. P. M. restitvti explicatio S.D.N. Clementis VIII. P. M. Ivssv edita. Auctore Christophoro Clavio Bambergensi Societatis Iesv. Accessit confutatio eorum, qui calendarium aliter instaurandum esse contenderunt. Romæ, apud Aloysium Zannettum, Ex svperiorvm permissv. cvm privilegio, MDCIII [1603].

Collani, Claudia von (1994): „RUGGIERI, Michele SJ“, In: Traugott Bautz (Hrsg.). Biographisch-Bibliographisches Kirchenlexikon (BBKL). Band VIII, Herzberg, Verlag Traugott Bautz GmbH, 979-981. Dostupné online za předplatné na: <http://www.bbkl.de/lexikon/bbkl-artikel.php>; Collani, Claudia von (b.d.). „Biographie von Michele Ruggieri SJ, Chinamissionar“. Dostupné online na: <http://stochastikon.no-ip.org:8080/ encyclopedia/de/ruggieriMichele.pdf $>$.

Collani, Claudia von (1997): „VALIGNANO, Alessandro SJ“, In: Traugott Bautz (Hrsg.). Biographisch-Bibliographisches Kirchenlexikon (BBKL). Band XII, Herzberg, Verlag Traugott Bautz GmbH, 1092-1096. Dostupné online za predplatné na: <http://www.bbkl.de/lexikon/bbkl-artikel.php>; Collani, Claudia von (b.d.). „Biographie von Alessandro Valignano SJ, Organisator der fernöstlichen Mission“. Dostupné online na: <http://stochastikon.no-ip.org:8080/encyclopedia/de/valignanoAlessandro.pdf $>$.

Collani, Claudia von (1998): „XAVIER, Franz (Francisco de Jasu y Xavier)“, In: Traugott Bautz (Hrsg.). Biographisch-Bibliographisches Kirchenlexikon (BBKL). Band XIV, Herzberg, Verlag Traugott Bautz GmbH, 269272. Dostupné online za předplatné na: <http://www.bbkl.de/lexikon/ bbkl-artikel.php>; Collani, Claudia von (b.d.). „Biographie Francisco de Xavier y Jasu SJ, Missionar und ,Apostel von Ostasien “. Dostupné online na: <http://stochastikon.noip.org:8080/encyclopedia/de/xavierFrancisco.pdf $>$.

Cruz, Gaspar da (1569): Tractado em que se cõtam muito por estẽso as cousas da China, cõ suas particularidades, e assi do reyno dormuz, cõposto por el R. padre frey Gaspar da Cruz da ordẽ de sam Domingos. Dirigido ao muito poderoso Rey dom Sebastiam nosso señor. Impresso com licença. Na konci je datace: Foy impresso este tratado da China, na muy nobre e sempre leal cidade de Euora em casa de Andre de Burgos. Acabouse aos 20 dias de Feuereiro de 1570.

Jordão, Levy Maria (ed.) (1868): Bullarium Patronatus Portugallice Regum in Ecclesiis Africe, Asice Atque Oceanice Bullas ... Actaque Sanctoe Sedis Ab Alexandro III. Ad Hoc Usque Tempus Amplectens, Curante Levy Maria Jordão. Tomus I. Olisipone, Ex typographia nationali, MDCCCLXVIII [1868].

Rada, Martín de (1575): Relaçion Verdadera delascosas del Reyno de TAIBIN por otro nombre china y del viaje que ael hizo el muy Reverendo padre fray martin de Rada provinçial que fue delaorden delglorioso Doctor dela yglesia San Agustin. quelo vio yanduvo en la provinçia de Hocquien año de 1575 hecha porelmesmo. Bibliothèque Nationale de Paris, Fonds Espagnol, 325.9 (MF 13184), f. 15-30.

Ruggieri, Michele 羅明堅 (1584): 天主聖教實錄 / Compendium legis divince a P. Michael Ruggiero, S.J. 廣東肇慶. Borg.Cin 324, Vatikánská knihovna.

Ruggieri, Michele - Ricci, Matteo; Witek, John W., ed. (2001): Dicionário Português-Chinês, 葡漢辭典 (Pu-Han cidian), Portuguese-Chinese dictionary. Macau - San Francisco, Biblioteca Nacional Portugal, Instituto Português do Oriente, Ricci Institute for Chinese-Western Cultural History.

Streit, Robert - Dindinger, Johannes - Rommerskirchen, Johannes - Kowalsky, Nikolaus (1964): Bibliotheca missionum. Bd. 4. Asiatische Missionsliteratur 1245-1599. 2., unveränd. Aufl. Freiburg, Herder, 1964; Bd. 5. Asiatische Missionsliteratur 1600-1699. 2., unveränd. Aufl. Freiburg, Herder, 1964. 


\section{Literatura}

Borao, José Eugenio (2009): Macao as the non-entry point to China: The case of the Spanish Dominican missionaries (1587-1632), International Conference on The Role and Status of Macao in the Propagation of Catholicism in the East, Macao, 3-5 November 2009, Centre of Sino-Western Cultural Studies, Istituto Politecnico de Macao. Dostupné $\mathrm{z}<\mathrm{http}$ ://homepage. ntu.edu.tw/ borao/2Profesores/Macao\%20Gate.pdf $>$.

Braga, J. M. (José Maria) (1949): The Western pioneers and their discovery of Macao. Macau, Imprensa Nacional.

Buben, Milan M. (2006): Encyklopedie řádio, kongregací a řeholních společností katolické církve v českých zemích. III. díl, 1. svazek, Žebravé řády. Praha, Libri, $471 \mathrm{~s}$.

Cieslik, Hubert (1954): Baltasar Gago and Japanese Christian Terminology, Missionary Bulletin, 8, 82-90.

D’Elia, Pasquale Maria (1938): Il mappamondo cinese del p. Matteo Ricci, S. I. (3. ed., Pechino, 1602) conservato presso la Biblioteca Vaticana. Città del Vaticano, Biblioteca apostolica Vaticana.

Dehergne, Joseph, S.J. (1940): Les origines du christianisme dans l'île de Hainan: (XVI ${ }^{\mathrm{ème}}$ - XVII ${ }^{\mathrm{ème}}$ siècles), Monumenta Serica, 5 (1/2), 329-348.

Etulain, Richard W. - Echeverria, Jeronima (1999): Portraits of Basques in the New World. Reno (NV), University of Nevada Press.

Fidlerová, Alena A. - Andrle, Jan et al., eds. (2010): Františku nebeský, vyslanče přesmořský. Podoby úcty $k s v$. Františku Xaverskému v českých textech 17. a 18. století. Př́ibram, Pistorius \& Olšanská.

Iraburu, José María (2003): Hechos de los apóstoles de América. Pamplona, Fundación Gratis Date, (3a edición).

Jann, Adelhelm (1915): Die katholische Mission in Indien, China und Japan. Ihre Organisation und das portugiesische Patronat vom 15. bis ins 18. Jahrhundert, von Dr. P. Adelhelm Jann O. Min. Cap. Paderborn, Druck und Verlag von Ferdinand Schöningh.

Kolmaš, Josef (1999): Akomodace, předchůdce aggiornamenta? Na př́íladu katolických misií v Číně, Bulletin Jesuité, 8(1): 26-28, 2: 26-27, 3: 27-28, 4: 28-29, 5: 25-27.

Lach, Donald F. (1965): Asia in the Making of Europe, vol. 1: The Century of Discovery. Book 1. Chicago and London, The University of Chicago Press.

Menachery, George, ed. (1973): The Saint Thomas Christian Encyclopedia of India. Trichur, B.N.K. Press.

Menachery, George, ed. (1998): The Indian Church History Classics. Vol. I, The Nazranies. Ollur (India).

Menachery, George et al. (1987): Kodungallur: City of Saint Thomas. Azhikode (nakladatel neznámý).

Ostolaza, Ma Isabel (2006): Fray Martín de Rada, evangelizador, cosmógrafo y embajador en China, Huarte de San Juan. Geografía e Historia, 13, $177-198$.

Piccinini, Chiara (2011): Shengmaerding Jingyuan (St Martin House / la casa di San Martino) in Macao as the First School of Western Missionaries for Teaching Chinese / 澳門聖瑪爾定經院作為西方傳教士們的第一所漢 語學校, In: The Sixth Fu Jen University International Sinological Symposium: „Early European (1552-1814) Acquisition and Research on Chinese Languages“ Symposium Papers / 輔仁大學第六屆漢學國際研討會: 《西方早期（1552-1814）漢語學習和研究論文集》. Ed. Zbigniew Wesołowski. New Taibei, Fu Jen Catholic University Printing House.
Pinch, William R. (2011): The Corpse and Cult of St. Francis Xavier, 15521623. In: Schmalz, Mathew N. - Gottschalk, Peter, eds. Engaging South Asian Religions: Boundaries, Appropriations, and Resistances. New York, State University of New York Press.

Sebes, Joseph (1988): The Precursors of Ricci. In: Ronan, Charles. E. - Oh, Bonnie C. (eds.). East Meets West. The Jesuits in China, 1582-1773. Chicago, Loyola University Press, 19-61.

Standaert, Nicolas, ed. (2001): Handbook of Christianity in China, vol. I: 6351800. Leiden - Boston - Köln, Brill.

Teixeira, Manuel (1970): D. Melchior Carneiro. Fundador da Sta. Casa da Misericordia de Macau. Macau, Tipografía da Missão do Padreado.

Teixeira, Manuel (1976): Bispos, Missionários, Igrejas e Escolas: no IV Centenário da Diocese de Macau, (Macau e a sua Diocese, Vol. 12). Macau, Tipografia da Missão do Padroado.

Tellechea Idígoras, José Ignacio (1993): Expedición franciscana a Cochinchina y China. La relación inédita de Fray Diego de San José (1583), Archivo Ibero-Americano, 53, 449-487.

Urschel, Donna (2010): Rare 1602 World Map, the First Map in Chinese to Show the Americas, on Display at Library of Congress, Jan. 12 to April 10, News from the Library of Congress. Washington, D.C.: Library of Congress.

Vlčková, Zdeňka (2007): Misionářská činnost Františka Xaverského - proměny církevního obrazu. Brno, Masarykova univerzita, Filozofická fakulta, Ústav religionistiky (bakalářská diplomová práce; dostupné z: <http:// is.muni.cz/th/145954/ff_b/Frantisek_Xaversky.doc >).

Wicki, José (1952): As "anotações" do P. Manuel Teixeira a sua "vida do B.P. Francisco Xavier" (1581), Boletim do Instituto Vasco de Gama, n69 (1952), Número comemorativo do IV centenário da morte de S. Francisco Xavier, 39-63.

Zwettler, Otto (1995): Tordesillaská smlouva z roku 1494, Historický obzor, $6(1), 5-7$.

\section{AUTOR}

Liščák, Vladimír (9. února 1954), český sinolog. Vědecký pracovník Orientálního ústavu Akademie věd České republiky, v. v. i. Zabývá se zejména styky mezi středověkou Evropou a mongolskou východní Asií (13.-14. století) a dějinami katolických misií v Číně. Je autorem řady článků v češtině, angličtině a několika knih, např. Čína Dobrodružství Hedvábné cesty (2000), Dějiny Č́ny, Taiwanu a Tibetu $v$ datech (2008), Konfuciánství od počátkư do současnosti. Dějiny pojmy - osobnosti (2013), Po stopách bratra Odorika. Styky Evropy a mongolské Č́ny ve 13. a 14. století (s př́lohou Biblioteca Odoriciana) (2014), Františkánské misie v Číně (13.-18. stoletî) (2015).

Kontakt: PhDr. Vladimír Liščák, CSc. Oddělení východní Asie, Orientální ústav Akademie věd České republiky, Pod Vodárenskou věží 4, 18208 Praha 8, e-mail: vliscak@orient.cas.cz 